\title{
Flood Inundation Mapping of Cempaka Tropical Cyclone Effect in Gunung Sewu Karst Landscape Using Sentinel 1
}

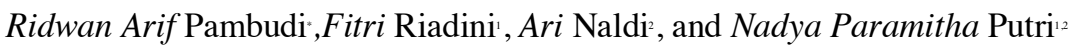 \\ Department of Geography, Faculty of Mathematics and Natural Science, Universitas Indonesia, \\ Depok, Indonesia \\ 2School of Environmental Science, Universitas Indonesia, Jakarta, Indonesia
}

\begin{abstract}
Cempaka Tropical Cyclone (TC) occurred on November 27, 2017, at the Indian Ocean and induced high rainfall leading to flooding in the southern part of Java island. One of the most affected areas is the karst landscape of Gunung Sewu. This study aims to identify flood inundated areas caused by the Cempaka TC in the Gunung Sewu karst landscape through satellite imagery of Sentinel 1B. Sentinel 1B imageries were used to extract the flood inundation area through the processing of random forest (RF) and the thresholding value (TV). A significant difference in flood inundated area was obtained between RF and TV, where RF shows a result of 526.07 ha of the total inundated area while the TV shows a result of 105.46 ha. However, both methods show the same sequence for three regencies with the highest total flood inundated area (Gunungkidul, Pacitan, and Wonogiri) and show the same range of each flood inundated area (0-0.5 ha). This distribution of flood inundated area can be used by policymakers as a basis for spatial planning in Gunung Sewu karst landscape.
\end{abstract}

\section{Introduction}

Cempaka Tropical Cyclone (TC) that reached its mature stage on 27 November 2017 in Indian Oceania raised the rainfall in southern part of Java Island significantly $[1,2]$. The District of Gunungkidul, Wonogiri, and Pacitan were the most affected region of that cyclone with average daily rainfall of 286-383 mm/day between 27 to 29 November 2017 which caused flooding in the area of Gunung Sewu karst landscape [3-5]. That flood caused at least 41 fatalities and gave economic loss as much as Rp1,13 trillion [6].

The mapping of flood inundation is prevalent in the context of future disasters effect prevention [7]. The result of flood inundation mapping has much benefit to raise public awareness and to improve the assessment for future disaster condition [8,9]. Aerial photogrammetry and optical satellite imagery have been well known as acquisition methods for flood inundation mapping [10-13]. However, aerial photogrammetry is expensive and discontinued, meanwhile optical satellite imagery is often hampered by the cloud [14-16].

\footnotetext{
*Corresponding author: ridwan.arif@ui.ac.id
} 
In facing those kinds of problem, the technology which based on synthetic aperture radar (SAR) could be a solution for that $[9,12,16-18]$. Sentinel 1 is one of SAR satellite imageries with C-Band censor $(5.405 \mathrm{GHz})$ which has got more advance features such as the ability to cut through the clouds, mission continuity, high spatial resolution, moderate temporal resolution, and available for free [15,19-22]. However, it is still utilized rarely to map flood inundation in a tropical karst landscape.

This research aims to identify flood inundated areas whereby caused by Cempaka TC in Gunung Sewu karst landscape. This research used random forest (RF) and thresholding value (TV) to identify the flood inundated areas. The results from both methods were used to gain more information to understand the hydrology characteristics of Gunung Sewu karst landscape and become an academic based input for related policymakers and other stakeholders to be more prepared to prevent the harmful effect of the same or more/less exacerbated flood in Gunung Sewu karst landscape in the future.

\subsection{Study Area}

Administratively, the karst area of Gunung Sewu stretches along 88 kilometres in the southern part of the three provinces namely the Special Region of Yogyakarta (Gunungkidul District), Central Jawa (Wonogiri District) and East Jawa (Pacitan District) with an area of around 1,315 km2 (Fig. 1). Geomorphologically, the Gunung Sewu karst area is an open karst landscape (bare/nackter karst) with a very typical karst topography in the form of conical hills, which is thousands of dull hills that are not steep (kegelkarst) as the rest of the dissolution process [23]. Based on the classification of carbonate rocky area types, the Gunung Sewu karst area is included in the holokarst type which is a karst type that has many caves, small holes, subsurface rivers, and springs [24].

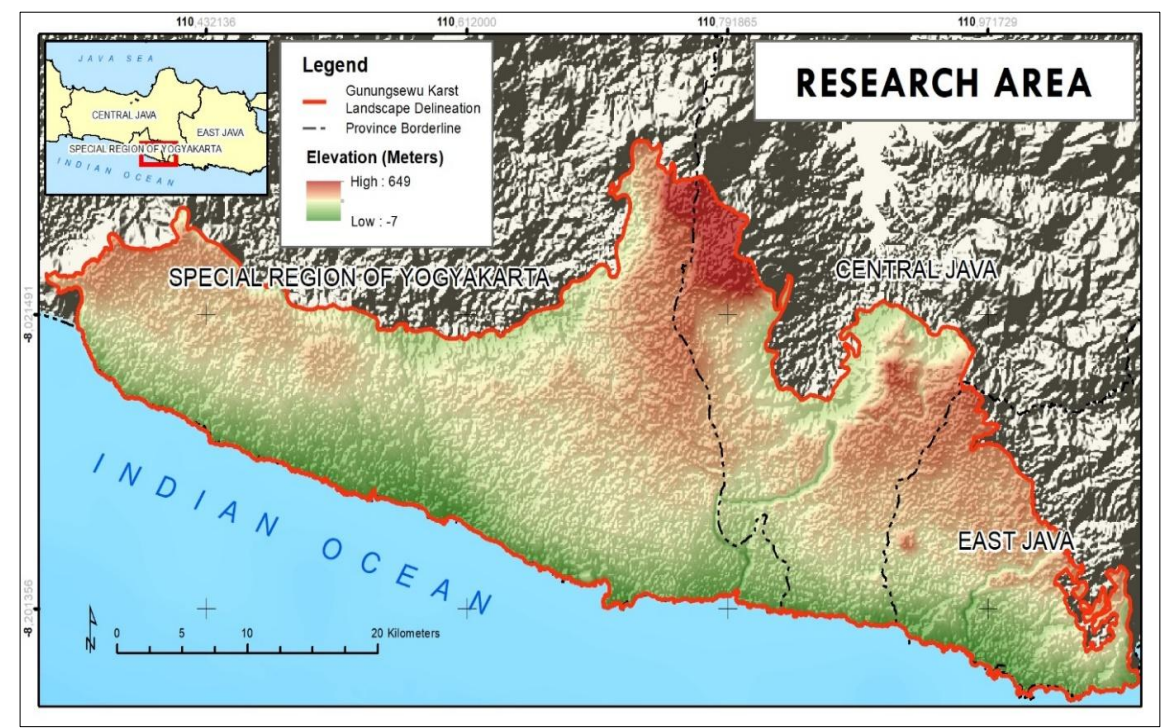

Fig. 1. Research Area

Karst hydrology has a uniqueness of how water flows to the underground through triple porosity (diffuse, fissure, conduit) with two groundwater recharge systems, 1) allogenic, where surface rivers from non-karst areas flow into underground river passages (conduit) and 2) autogenic, where water on the surface of the karst area seeps into underground rivers 
through the soil pores (diffuse) or fractures (fissures) [25, 26]. This causes the surface river in the Gunung Sewu karst area to be very minimal, but many underground rivers and hundreds of springs that have a large discharge are well developed [27, 28]. The hydrological condition also makes flooding in the Gunung Sewu karst unique because it is a flooding phenomenon that involves surface runoff and groundwater runoff [25].

\section{Materials and Methods}

\subsection{Materials}

The map of flood inundation is generated from two satellite imageries of Sentinel 1B which was acquired at the moment before the flood (21 November 2017) and when the flood occurred (3 December 2017). The satellite imagery of Sentinel 1B with the feature of 20 metres azimuth resolution and 5 metres ground range resolution is provided by European Space Agency (ESA) in order to global monitoring for Environment and Security (GMES) and can be downloaded through https://asf.alaska.edu [29]. The detailed information of the Sentinel 1B imagery that was used for this research is shown in Table 1.

Table 1. Detailed Information of Sentinel 1B Images

\begin{tabular}{ccc}
\hline \multirow{2}{*}{ Parameters } & \multicolumn{2}{c}{ Descriptions } \\
\cline { 2 - 3 } & $\begin{array}{c}\mathbf{2 1}^{*} \text { November 2017 } \\
\text { (archive image) }\end{array}$ & $\begin{array}{c}\mathbf{3}^{\text {rd }} \text { December 2017 } \\
\text { (crisis image) }\end{array}$ \\
\hline Type & Ground Range Detected & Ground Range Detected \\
& $($ GRD) & (GRD) \\
Path/Frame & $127 / 1151$ & $127 / 1151$ \\
Beam Mode & Interferometric Wide (IW) & Interferometric Wide (IW) \\
Flight Direction & Ascending & Ascending \\
Polarisation & VV & VV \\
Absolute Orbit & 8378 & 8553 \\
\hline
\end{tabular}

\subsection{Materials}

In general, to gain the information of flood inundated area, the imagery data of Sentinel 1B must pass out the pre-processing and processing stage. Pre-processing stage aims at preparing the raw data to become dataset which is ready to be processed or extracted [30]. Preprocessing stage consists of subset, multi-looking, calibration, speckle filter, and Range Doppler Terrain Correction, as shown on Figure 2.

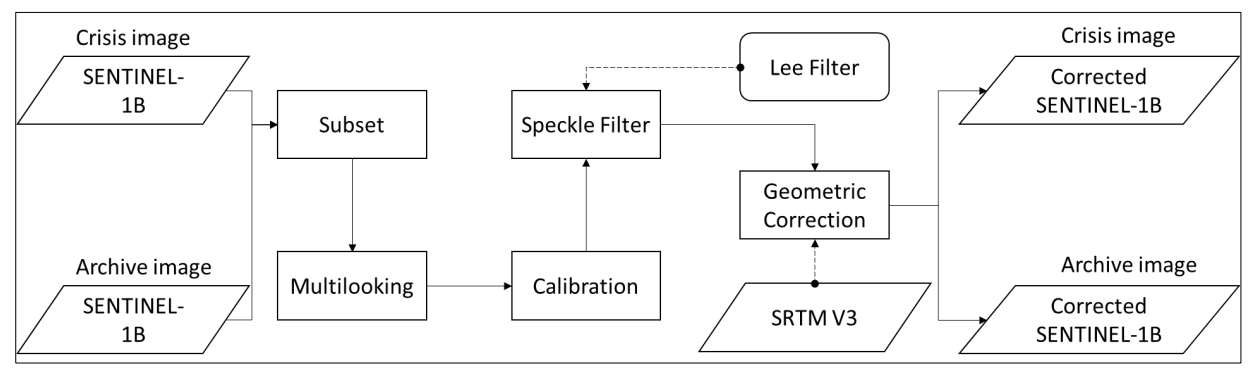

Fig. 2. Pre-processing Step of Sentinel-1B 
First, the subset stage is achieved by more precisely cutting satellite imagery in the study area. This stage aims to minimize the data size so that that processing can be accelerated at a later level [31]. Second, to change the spatial resolution from $10 \mathrm{~m}$ to $15 \mathrm{~m}$, multi-looking is applied. The purpose of this stage is to reduce the processing time at a later stage because the image size is several times smaller than the original [32]. Third, the image is radiometrically calibrated by converting the raw image value from a digital number to the radar backscatter coefficient $\left(\sigma^{\circ}\right)[32,33]$. Fourth, to reduce speckle noise, Lee Filter with 3 x 3 multi-looking is applied, the size represents a good compromise between preservation of spatial detail and the signal-to-noise ratio [32-34]. Lastly, geometric correction (geo-coding) in the form of Range Doppler Terrain Correction is conducted with Shuttle Radar Topography Mission (SRTM V3), so that the image is precisely projected and ready for further processing at the processing stage $[32,33,35]$.

Processing stage in this research was conducted by two methods, RF and TV. In principle, RF is imagery classification method by building a big decision tree (Fig. 3) [36]. RF method needs training data as its input to result classification, the large number of trees will provide a stable result of variable importance [37]. The result of RF was decided by the voice majority within the trees [38].

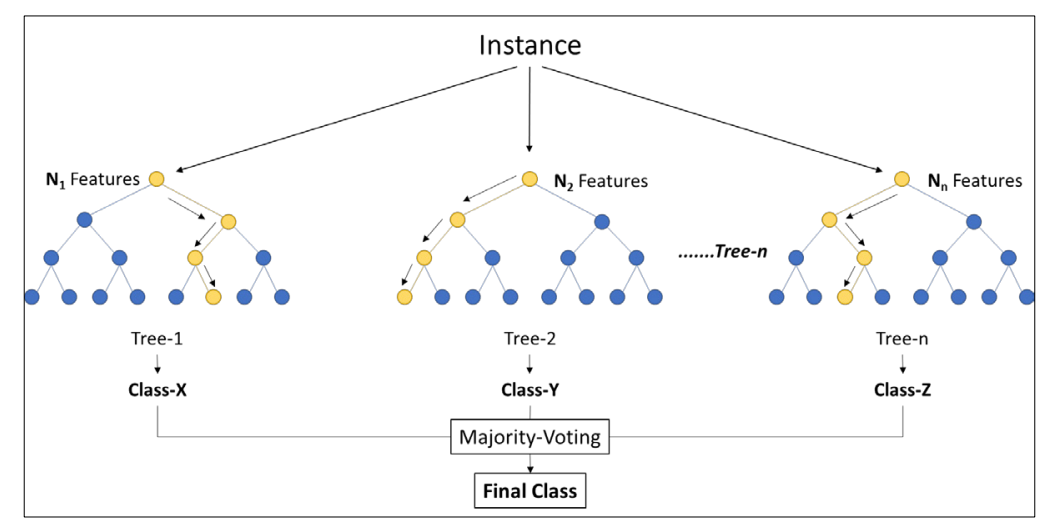

Fig. 3. Concept of RF adapted from $[39,40]$

TV is a method to detect object in imagery by utilizing the value of imagery backscatter which was taken from (Fig. 4) $[10,41]$. The identified value was becoming the limit value that was applied into band math to generate segregated imagery (function 1). The whole processing stage was done by using software of Sentinel Application Platform (SNAP) 7.03 (Fig. 5 and Fig. 6). 

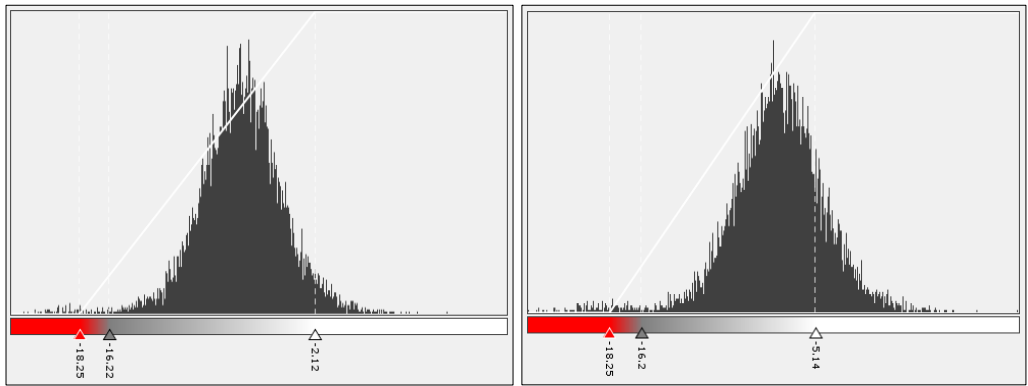

Figure 4. Histogram of archive (left) and crisis images (right)

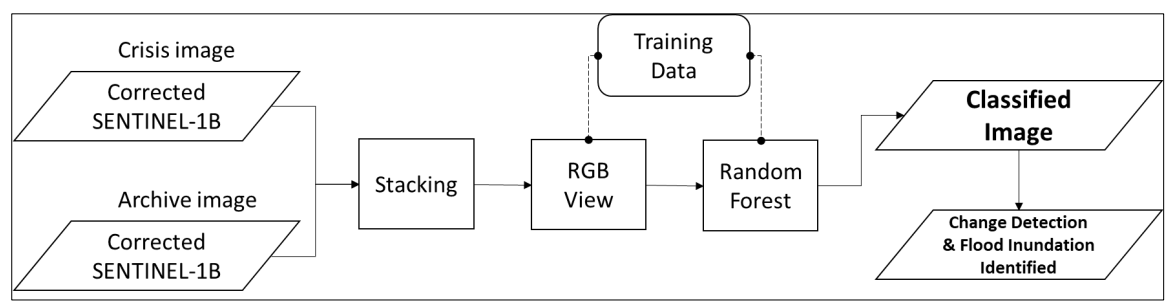

Figure 5. Workflow of RF Processing Method

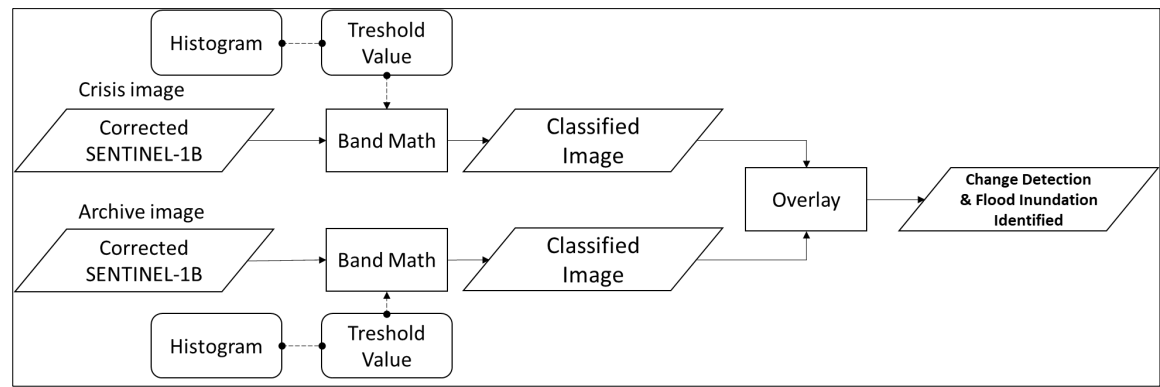

Figure 6. Workflow of TV Processing Method

\section{Results and Discussions}

Sentinel 1 satellite imagery with its advantages in the form of cloud penetration capability, mission continuity, high spatial resolution and moderate temporal resolution is undergoing rapid development to map flood inundation today [15,19-22]. However, the use of Sentinel 1 satellite imagery in mapping flood inundation in the karst landscape has never been achieved in previous studies. In this study, we found that the RF and TV methods could be used to map inundation in the karst region.

The mapping findings using the RF and TV approaches reveal vast differences in the extent and distribution of flooded areas. The extent of flooded areas in the Gunung Sewu karst landscape due to Cempaka TC is 526.07 ha based on the RF method, whereas the flooded area is 105.46 ha based on the TV method. Although there are significant differences in the extent of flooded areas, both methods show that Gunungkidul District is the region 
with the most severe flood inundation among the three districts located in the Gunung Sewu karst landscape (Table 2).

Table 2. Amount of flood inundation areas

\begin{tabular}{cccc}
\hline \multirow{2}{*}{ Methods } & \multirow{2}{*}{ Regencies } & \multicolumn{2}{c}{ Area (Ha) } \\
\cline { 3 - 4 } & Permanent Water Bodies & Flood Inundation \\
\hline \multirow{2}{*}{ RF } & Gunungkidul & 2.38 & 272.80 \\
& Pacitan & 10.61 & 128.65 \\
& Wonogiri & 3.68 & 124.62 \\
\hline \multirow{2}{*}{ TV } & Gunungkidul & 120.66 & 43.59 \\
& Pacitan & 54.04 & 43.89 \\
& Wonogiri & 64.35 & 17.98 \\
\hline
\end{tabular}

Based on the extent of flood inundation per village, the RF Method shows that $73 \%$ of the 146 villages in the Gunung Sewu karst landscape have flood inundation ranges of 0-5.0 ha, followed by the other $21 \%$ within 5.1-10.0 ha (Figure $7 \mathrm{a}$ and 8 ). The dominance of flood inundation ranges of $0-5.0$ ha in the RF Method is consistent with the findings of the TV Method which shows that $96 \%$ of 146 villages in Gunung Sewu's karst landscape have flood inundation ranges of $0-5.0$ ha (Fig. $7 \mathrm{~b}$ and 9 ).

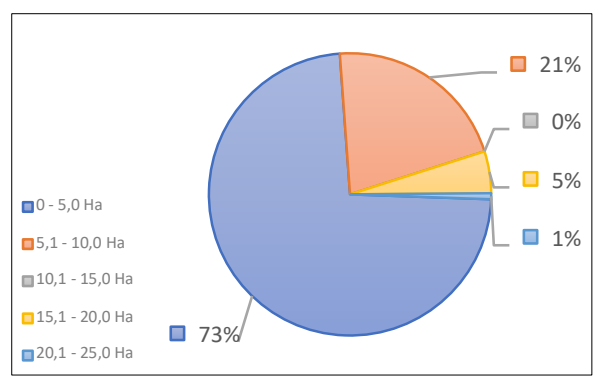

Fig. 7a. Percentage of flood inundation area range in villages of Gunung Sewu karst landscape based on RF method

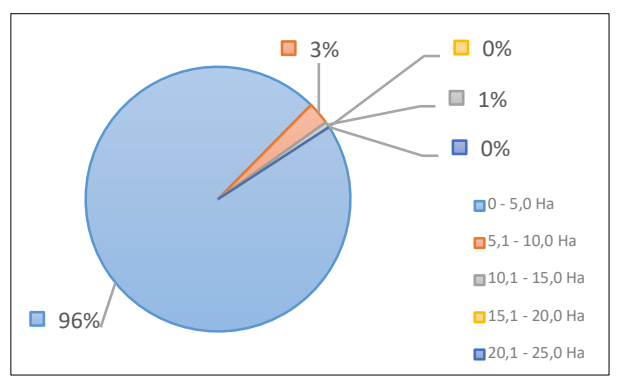

Fig. 7b. Percentage of flood inundation area range in villages of Gunung Sewu karst landscape based on TV method

In minimizing the risk of flooding due to TC in the Gunung Sewu karst landscape in the future, it is essential to know the trend of flood inundation area and the region most affected within the village administration unit. There is a tendency, based on RF and TV methods that villages in the southern part have broader flood inundation compared to those in the central and northern part of the Gunung Sewu karst landscape (Fig. 8 and Fig. 9). The villages with the most extensive flood inundated area based on RF method include Pucung Village (20.79 ha), Pacarejo (13.39 ha), and Jepitu (13.38 ha), which is almost similar to the results of TVbased mapping showing Pucung Village (14.52 ha), Pacarejo (9.69 ha), and Piton (8.23 ha) as the most extensive flood inundated villages. (Table 3 ). Despite being the villages that most prone to flood inundation due to Cempaka TC, the flood that pooled in these villages has been identified as still outside the residential area (Fig. 8 and Fig. 9). 

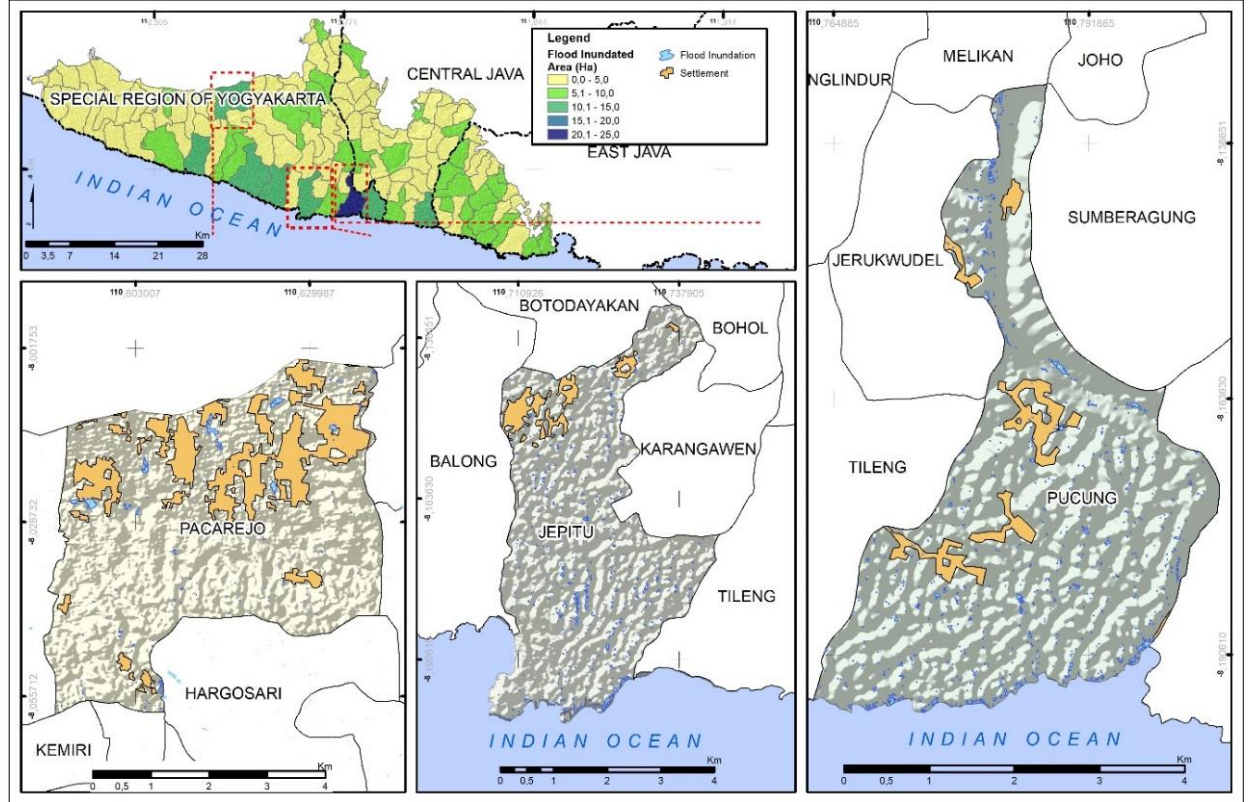

Figure 8. The worst flood inundated area based on RF method

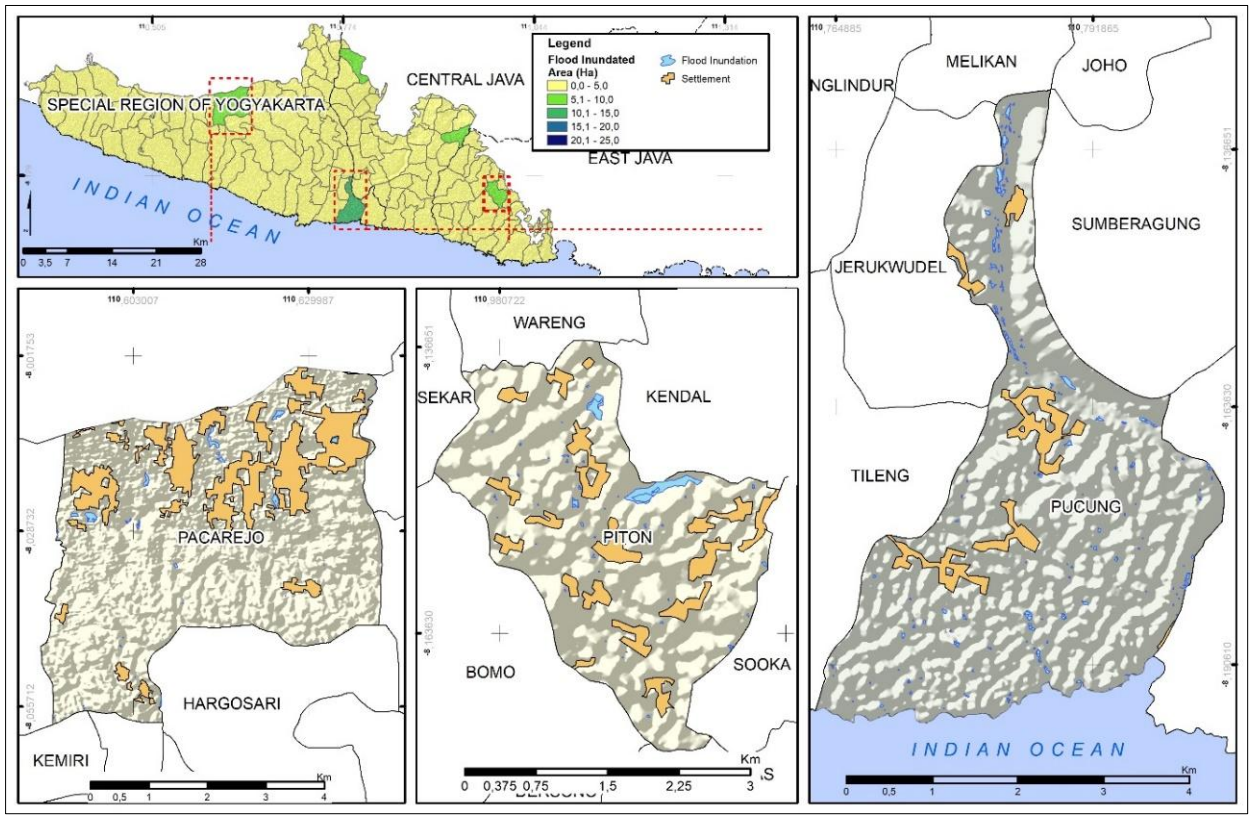

Figure 9. The worst flood inundated area based on TV method 
Table 3. The worst villages inundated by flood

\begin{tabular}{cllc}
\hline Methods & Villages & Regencies & Area (Ha) \\
\hline \multirow{3}{*}{ RF } & Pucung & Gunungkidul & 20.79 \\
& Pacarejo & Gunungkidul & 13.39 \\
& Jepitu & Gunungkidul & 13.38 \\
\hline \multirow{3}{*}{ TV } & Pucung & Gunungkidul & 14.52 \\
& Pacarejo & Gunungkidul & 9.69 \\
& Piton & Pacitan & 8.23 \\
\hline
\end{tabular}

This research has pluses including (i) the use of two easily implemented flood-inundation mapping methods and (ii) the scale of the research area covering the entire karst landscape of Gunung Sewu. The use of village administration as an analytical unit in describing floodwater distribution enriches the discussion of research findings and makes it easier for stakeholders to prepare mitigation plans. The inherent shortcomings in this research, however, are the limited availability of Sentinel 1 satellite images acquired just after the 2729 November 2017 rainfall event and the narrow range of radar backscatter values between standing water and steeply sloped area.

The limited availability of Sentinel 1 imagery acquired just after November 27-29, 2017 has implications for flood inundation mapping results which do not reflect flood inundation under maximum conditions. However, this can occur only five days apart (29 November 2017 to 3 December 2017), due to the channelling of surface water through a conduit flow and diffuse flow system, as water tends to be more easily infiltrated into the saturation zone vertically below the rock layer [25,26,42-44]. On the other hand, the narrow range of radar backscatter values between standing water and the steeply sloped areas often found in the Gunung Sewu karst landscape in the form of conical hills makes the results of flood inundation detection using the RF and TV methods are not entirely accurate with a tendency to overestimation (Fig. 10)[45,46].

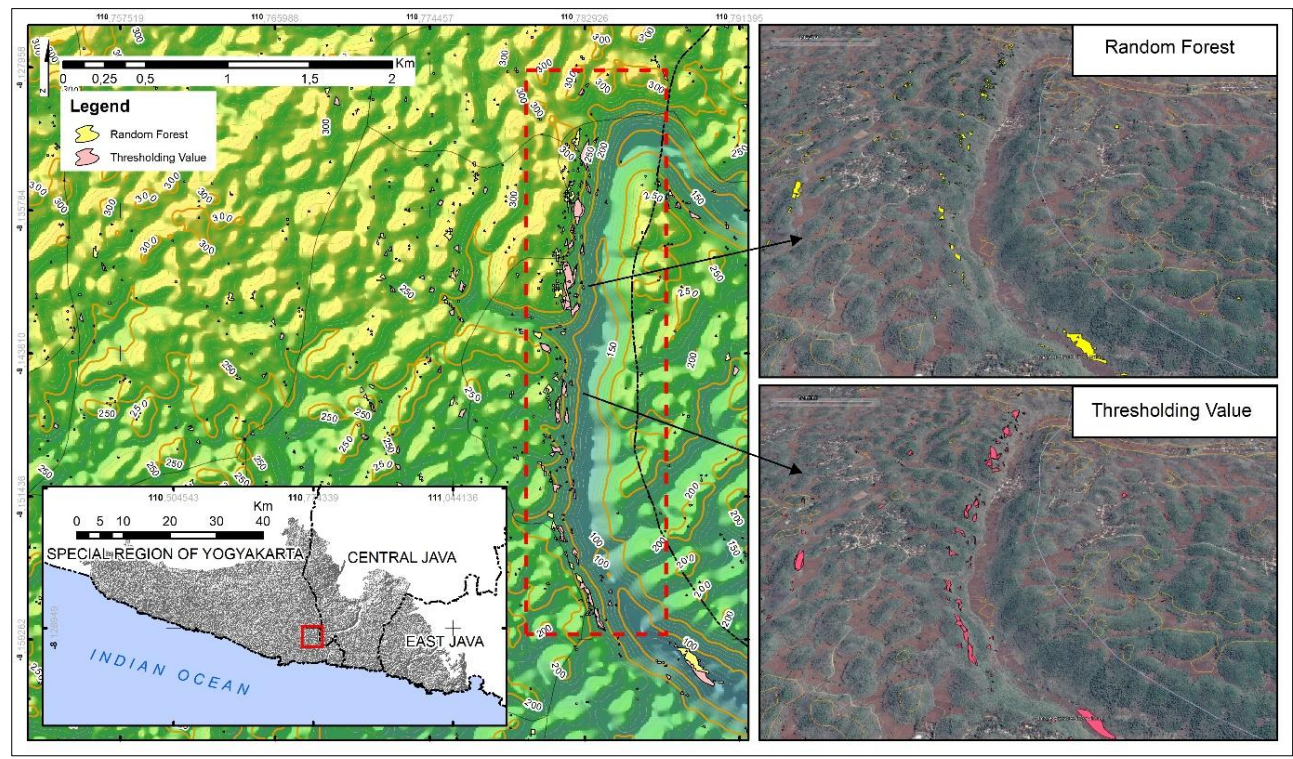

Figure 10. Instance of steep area was identified as flood inundation on the Ancient of Bengawan Solo

Our research confirms previous research findings which stated that SAR-based imagery with RF and TV methods could be used in mapping flood inundation regardless of weather 
conditions $[11,19,34,35]$. In addition, this study also contributed to the research results of Ahmad et al. (2019) [25] and reports from National Disaster Management Authority (2017) $[5,6]$ in terms of the comprehensive distribution of flood inundation in the Gunung Sewu karst landscape. For similar studies in karst landscapes with steep terrain, it is recommended that the results of flood detection should be processed first by considering the landforms and terrain obtained from digital elevation model (DEM) or digital terrain model (DTM) so that flood inundation areas and areas with steep slopes may be differentiated [46]. Research results in the form of flood inundation due to Cempaka TC have practical implications in the form of recommendations in spatial plans to avoid the development of settlements and infrastructures that are not linked to water management so that the number of deaths and economic losses due to flooding caused by TCs in the Gunung Sewu karst landscape can be minimized in the future $[47,48]$.

\section{Conclusion}

Cempaka TC has caused flooding that has claimed lives and has damaged the communities' economy around the Gunung Sewu karst landscape. The mapping of flood inundation using Sentinel 1B needs to be done as an emergency response and disaster mitigation effort. Based on the RF and TV methods, the flood area that inundates the Gunung Sewu karst landscape is 526.07 ha and 105.46 ha, respectively, with Gunungkidul District being the region with the most flood inundation. Floods inundated area of 0-5.0 ha prevails at the village level, with the likelihood that villages in the southern part have immense flooding compared to villages in the central and northern part of the Gunung Sewu karst landscape. The distribution of flood inundation due to Cempaka TC needs to be the basis for policymakers to consider in preparing spatial plans to deal with the dangers of TCs in Gunung Sewu karst landscape in the future, in minimizing the casualties and economic loss.

\section{References}

1. I. J. A. Saragih, P. A. Sugianto, M. P. Rosyady, and A. Kristianto, in Semin. Nas. Penginderaan Jauh Ke-5, edited by F. Muchsin, S. Sulma, Mukhoriyah, N. Anggainin, R. P. Brahmantara, and U. C. Nugroho (Pusat Teknologi dan Data Penginderaan Jauh - LAPAN, Depok, 2018), pp. 864-871

2. R. Mahubessy, A. K. Silitonga, G. P. Lumbantobing, and H. A. Rejeki, in Proceeding Mar. Saf. Marit. Install., edited by K. B. Artana and D. W. Handani (Clausius Scientific Press, Bali, 2018), pp. 104-109

3. F. Samrin, I. Irwana, Trismidianto, and N. Hasanah, in Int. Conf. Trop. Meteorol. Atmos. Sci. (IOP Publishing, Bandung, 2019)

4. Y. S. Swarinoto, A. W. Putra, E. Fibriantika, and N. Alfuadi, Int. J. Sci. Basic Appl. Res. 43, 117 (2019)

5. Badan Nasional Penanggulangan Bencana, Info Bencana Edisi November 2017 (Jakarta, 2017)

6. Badan Nasional Penanggulangan Bencana, Data Bencana Indonesia 2017 (Pusat Data, Informasi, dan Humas Badan Nasional Penanggulangan Bencana, Jakarta, 2017)

7. K. M. Brown, C. H. Hambidge, and J. M. Brownett, Prog. Phys. Geogr. 40, 196 (2016)

8. B. Tomaszewski, Geographic Information Systems ( GIS ); A Tool for Disaster Management (CRC Press, Boca Raton, 2014)

9. G. R. Brakenridge and E. Anderson, in Transbound. Floods Reducing Risks Through Flood Manag., edited by J. Marsalek, G. Stancalie, and G. Balint (IOS Press, Amsterdam, 2006), pp. $1-12$ 
10. Z. N. Musa, I. Popescu, and A. Mynett, Hydrol. Earth Syst. Sci. 19, 3755 (2015)

11. Q. Feng, J. Liu, and J. Gong, Water 7, 1437 (2015)

12. D. P. Ward, A. Petty, S. A. Setterfield, M. M. Douglas, K. Ferdinands, S. K. Hamilton, and S. Phinn, Remote Sens. Environ. 147, 43 (2014)

13. J. Chormanski, T. Okruszko, S. Ignar, O. Batelaan, K. T. Rebel, and M. J. Wassen, Ecol. Eng. 37, 1334 (2011)

14. D. Mihajlovic, I. Nedeljkovic, and M. Soskic, in First Mediterr. Conf. Earth Obs., edited by R. Pavlović and D. Mihajlović (Beograd: Faculty of Mining and Geology, Remote Sensing Center, Belgrade, 2004)

15. A. K. Agnihotri, A. Ohri, S. Gaur, Shivam, N. Das, and S. Mishra, Environ. Monit. Assess. 191, (2019)

16. G. R. Brakenridge, E. Anderson, S. V. Nghiem, S. Caquard, and T. Shabaneh, in Proc. 30th Int. Symp. Reemote Sens. Environ. (Honolulu, 2003), pp. 1-6

17. P. Potin, B. Rosich, N. Miranda, and P. Grimont, in Int. Conf. Enterp. Inf. Syst., edited by Committee of CENTERIS 2016 (Elsevier Masson SAS, Porto, 2016), pp. 1297-1304

18. G. J.-P. Schumann, P. D. Bates, G. Di Baldassarre, and D. C. Mason, in Fluv. Remote Sens. Sci. Manag., edited by P. E. Carbonneau and H. Piégay (Wiley-Blackwell, Chichester, 2012), pp. 115-137

19. M. A. Clement, C. G. Kilsby, and P. Moore, J. Flood Risk Manag. 11, 152 (2018)

20. P. Potin, B. Rosich, J. Roeder, and P. Bargellini, in Int. Geosci. Remote Sens. Symp. (IEEE, Quebec, 2014), pp. 1465-1468

21. D. Geudtner, R. Torres, P. Snoeij, M. Davidson, and B. Rommen, in Int. Geosci. Remote Sens. Symp. (IEEE, Quebec, 2014), pp. 1457-1460

22. E. Attema, M. Davidson, P. Snoeij, B. Rommen, and N. Floury, in Int. Geosci. Remote Sens. Symp. (IEEE, Cape Town, 2009), pp. 36-39

23. T. N. Adji, in Semin. UGK-BP DAS SOP (Yogyakarta, 2004), pp. 1-10

24. A. Ashari, Geomedia 10,(2012)

25. A. Cahyadi, E. Haryono, T. N. Adji, M. Widyastuti, I. A. Riyanto, Y. T. Nurteisa, H. Fatchurohman, H. Reinhard, R. F. Agniy, A. Nurkholis, M. Naufal, and E. Nurjani, in Int. Conf. Energy, Environ. Epidemiol. Inf. Syst., edited by Hadiyanto, B. Warsito, and Maryono (E3S Web of Conferences, Semarang, 2019)

26. H. Fatchurohman, T. N. Adji, E. Haryono, and P. Wijayanti, in Int. Conf. Environ. Resour. Manag. Glob. Reg. (IOP Publishing, Bali, 2018)

27. A. Cahyadi, E. A. Ayuningtyas, and B. A. Prabawa, Indones. J. Conserv. 2, 23 (2013)

28. T. N. Adji, E. Haryono, H. Fatchurohman, and R. Oktama, Environ. Earth Sci. 76, 1 (2017)

29. European Space Agency, Sentinel-1: ESA's Radar Observatory Mission for GMES Operational Services (ESA Communications, Leiden, 2012)

30. F. Filipponi, Proceedings 18, 11 (2019)

31. D. Mandal, D. S. Vaka, N. R. Bhogapurapu, V. S. K. Vanama, V. Kumar, Y. S. Rao, and A. Bhattacharya, Preprint 1 (2019)

32. B. Pham-Duc, C. Prigent, and F. Aires, Water 9, 1 (2017)

33. J. H. Reksten and R. Solberg, in Int. Arch. Photogramm. Remote Sens. Spat. Inf. Sci., edited by T. Tanzi, O. Altan, M. Chandra, and F. Sunar (ISPRS, Prague, 2019), pp. 349-355

34. H. Cao, H. Zhang, C. Wang, and B. Zhang, Water 11, 1 (2019)

35. F. Bioresita, A. Puissant, A. Stumpf, and J. P. Malet, Remote Sens. 10, 1 (2018)

36. H. Balzter, B. Cole, C. Thiel, and C. Schmullius, Remote Sens. 7, 14876 (2015)

37. P. T. Noi and M. Kappas, Sensors 18, (2018)

38. R. Sonobe, H. Tani, X. Wang, N. Kobayashi, and H. Shimamura, Remote Sens. Lett. 5, 157 (2014) 
39. W. Koehrsen, Www.Medium.Com (2017)

40. B. Alghamdi and F. Alharby, J. Inf. Secur. 10, 155 (2019)

41. B. Zhang, S. Wdowinski, T. Oliver-Cabrera, R. Koirala, M. J. Jo, and B. Osmanoglu, in Int. Arch. Photogramm. Remote Sens. Spat. Inf. Sci., edited by J. Jiang, A. Shaker, H. Zhang, X. Liang, B. Osmanglu, U. Soergel, E. Honkavara, M. Scaioni, J. Zhang, A. Peled, L. Wu, R. Li, M. Yoshimura, K. Di, T. J. Tanzi, H. M. Abdulmuttalib, F. S. Faruque, U. Stilla, and U. Komp (ISPRS, Beijing, 2018), pp. 2237-2244

42. R. A. Pambudi, A. Damayanti, and K. Marko, in Padjajaran Earth Dialogues, Int. Symp. Geophys. Issues (IOP Publishing, Bandung, 2019)

43. S. B. Kusumayudha, Mengenal Hidrogeologi Karst, 1st ed. (Pusat Studi Karst LPPM UPN Veteran Yogyakarta, Yogyakarta, 2004)

44. D. Ford and P. Williams, Karst Hydrogeology and Geomorphology, 1st ed. (John Wiley \& Sons Ltd, The Atrium, Southern Gate, Chichester, West Sussex, 1989)

45. E. Haryono and M. Day, J. Cave Karst Stud. 66, 62 (2004)

46. S. Martinis, C. Kuenzer, and A. Twele, in Remote Sens. Water Resour. Disasters, Urban Stud., edited by P. S. Thenkabail (CRC Press, Boca Raton, 2016), pp. 1-659

47. J. Ran and Z. Nedovic-Budic, Comput. Environ. Urban Syst. 57, 68 (2016)

48. N. Pieterse, J. Tennekes, B. Van De Pas, K. Slager, and F. Klijn, Compr. Flood Risk Manag. 779 (2013) 